for some time after the current is switched on. The amount of change varies with the material and the amplitude of the alternating magnetisation.

In the Electrotechnics Division, apparatus was shown for analysing the motion of rapidly moving automatic switchgear. An oscillographic method is employed, and from the records it is possible to dotormine the velocity of the moving parts while the switch is being broken, and also the time taken to complete the breaking of the circuit.

In the Wireless Division the fundamental work on very short waves has been continued. For comparison with theory, an apparatus has been developed for the study of the propagation, along the earth's surface, of ultra-short waves of wave-length 1.6 metres. Measurements are made of the decrease of signal strength with distance, at a height up to about 5 metres. A small, single valve, retroaction type oscillator is used as the transmitter, and no aerial is employed. The intensity measurements are made from a distance, with the aid of a telescope, to avoid disturbances in the field due to the proximity of the observer.

Another interesting exhibit showed the production and measurement of osciliations of wave-lengths between 14 and 80 centimetres. These waves are produced by the oscillation of electrons about the grid, which occurs in some valves when the grid has a high positive and the anode a slightly negative potential with respect to the filament.

In connexion with the investigation of the effects of glare undertaken by the Photometry Division, a new form of photometric pupilometer has been devised. In this instrument the observer views an ordinary photometric field, both halves of which are illuminated by the Maxwellian method, in which the light source is focused at the observer's eye. The illuminant for one half of the field is a bright spot, the image of which is considerably less than the smallest diameter of the pupil of the eye. The other half of the field is illuminated by an extended surface, so that the amount of light received varies with the aperture of the pupil. By making a photometric balance it is possible to determine the size of the pupil.

In the High Voltage Division, two high voltage sources of direct current have been constructed, in corporating in one case full-wave and in the other half-wave rectification. The former, which is capable of giving 200 kilovolts, will be used for providing the accelerating voltage for an impulse generator and for general research. The latter, designed for 100 kilovolts, is primarily for use with a high voltage cathode ray oscillograph.

In the William Froude Laboratory, tests were being conducted with a model high speed steamer to determine the effects of rough water on the resistance of ship forms and upon the propeller efficieney, with the view of obtaining improved ship economy at sea. 'The model was entirely self-propelled through rough water created by the wave machine. Measurements were made of the speed, the power required to drive the model, and the thrust of the propellers. At the same time continuous records were made of the pitching of the hull. Of interest also was a model of an improved design of Thames barge constructed to the designs of the Laboratory. Comparative tests with barges of normal type have shown that with the new design a 33 per cent improvement in speed is obtained, while the power expenditure of the tug is slightly reduced.

\title{
International Congress of Prehistoric and Protohistoric Sciences
}

Now W that the programme is virtually complete, it is safe to predict success for the first International Congress of Prehistoric and Protohistoric Sciences, the first intermational archæological congress to meet in Great Britain since 1868. When the members assemble in London on Aug. 1, practically every nationality will be represented, and the communications to be submitted will afford a very fair conspectus of the more important departments of prehistoric research as it stands to-day. British archæological studies in various parts of the world, in particular, will be well represented.

Some proliminary information relating to the organisation of the Congress and the excursions of archæological interest which are to follow has already been given in NATURE (see March 26, p. 479) and need not be repeated. In addition to the communications which will be presented to the sections of the Congress at King's College and the presidential address, in which Sir Charles Peers will review the beginnings of archæological studies in Great Britain, discourses will be delivered at general meetings to be held in the evening on Tuesday, Wednesday, and Friday in the Congress week. The speakers will be: Dr. Cyril Fox, director of the National Museum of Wales, on the control of physical geography in the early history of human habitation; and Mr. E. 'T. Leeds, keeper of the Ashmolean Museum, Oxford, and Mr. T. D. Kendrick, of the British Museum, on the outstanding material expressions of the Celtic and Teutonic civilisations. A fourth general meeting on Saturday morning will be addressed by Mr. O. G. S. Crawford on " Air Photography and Archæology". Here may also be mentioned, as outside the sectional routine, though connected with the proceedings, a visit to the famous palæolithic gravel pit at Swanscombe and an extensive exhibition at Bedford College illustrative of the report which Miss Caton-Thompson will read on her investigation of the prehistory of the Kharga Oasis, Egypt.

Turning to the work of the sections, it is possible to mention here a very small selection only of the large number of papers which have been accepted and allocated to the programmes of the five sections into which the work of the Congress has been classified. In Section I. (Human Palæontology), under the presidency of Sir Arthur Smith Woodward, the most attractive topic undoubtedly will be the recently discovered human remains from Mount Carmel, Palestine. Of neanderthaloid type, but aberrant from that type, they will be described, perhaps exhibited, by Mr. T. McCown, the finder, and discussed by Sir Arthur Keith. The morphology and antiquity of man in America will be the subject of discussion by Dr. Bruno Oetteking, and Dr. L. S. B. Leakey will describe the fossil teeth of Miocene anthropoids recently found by him on the shore of Lake Victoria in East Africa and the circumstances of their discovery.

Mr. Reginald Smith, presiding over Section II., will be concerned with a variety of problems relating to the old stone age, ranging from Africa to the extremes of Europe and Asia. Dr. L. S. B. Leakey will deal with the prehistoric cultural sequences at Oldoway, Tanganyika, and Messrs. Miles Burkitt and E. J. Wayland will discuss the Mgosian culture of Uganda. Prof. R. Vaufrey's paper on the Acheulean of Gafsa, should be valuable. The Abbé Breuil will give the results of his first-hand observation on fire and the bone and stone implements in the cave of Peking man, and he will also review our present knowledge of palæolithic 
cave art. A department of the latter topic, the art of the Spanish caves, will be the subject of consideration by M. L. Pericot. Dr. B. S. Petri will describe the palæolithic culture of Siberia.

A number of members will deal with aspects of mesolithic culture: M. Reygasse on the Tardenoisian of North Africa, Prof. Antoniewicz on early man in north-east Poland and Lithuania, Prof. E. Plopson on Rumania, and Prof. R. Serpa da Pinto on Portugal.

Questions relating to the neolithic, bronze, and iron ages in the ancient world fall to the province of Section III., which being by far the largest section, has had to be subdivided. Cis-Alpine European prehistory, under Prof. H. J. Fleure, will devote considerable attention to megalithic monuments, with papers by Prof. Daryll Forde on the varied typology of Breton megaliths, the veteran M. Le Rouzic on the relative chronology of the prehistoric burials of the Morbihan, Prof. R. A. S. Macalister on the horned cairns of Ireland, Mrs. Cunnington on "Wooden Circles ', and Mr. H. St. George Gray on his exeavation of Avebury. The interest of this group is rivalled by Prof. Siret on the problem of the meneolithic age and M. Vouga on his investigations in the lake villages of Switzerland. Mr. C. A. R. Radford will describe the hill-villages of the south-west of England, Mr. Hencken will discuss the Cornish tin trade, and Mr. A. Keiller will give an account of the extremely important settlement which he has excavated at Windmill Hill. A question which has long demanded ventilation will be opened by Mr. Brynner Jones on the origin of British domestic cattle and especially the domestic ox.

In the section dealing with the Near East, under the joint presidency of Prof. J. L. Myers and Mr. Sidney Smith, importancewill be attached to Sir Arthur Evans's demonstration of the great cleavage between Knossos and Mycenæ in Late Minoan i.b. and the later unifying reaction from Crete. Mesopotamia is represented by, among others, Mr. Leonard Woolley on the early graves of Ur, Mr. Harden on painted pottery from Kish, and Dr. H. Frankfort on Syrian and Anatolian influences in Mesopotamia; while from Anatolia, Dr. $H$. van den Osten will describe the æneolithic settlement at Alishar in Cappadocia. There may also be mentioned Prof. Gordon Childe on the bearing of a newly discovered metal type from the east on European bronze age chronology, and Dr. O. Menghin on excavations at Beni Salameh in relation to their significance for European prehistory. This must suffice, though it is far from exhausting the list.

The section devoted to areas outside Europe will be much preoccupied with the archæology of beads, especially from Indian iron age burials in the Deccan, described by Mr. E. H. Hunt, and from China, the latter being designated as "of foreign origin". Prof. C. G. Seligman and Mr. Beck jointly will be responsible for the discussion of the latter, and Mr. Beck for the former.

The transition from prehistory to history, the work of Section V. under Mr. E. T. Leeds, deals with the movements of races, Saxons, Vikings, Slavs, etc., in the early centuries of our era. Dr. Schetelig, the foremost of Viking archæologists, will cover broadly the excursions of this people, and Prof. T. Balodis will discuss Lettish origins in this period. Tombs of the Roman iron age in North Jutland will be described by Prof. J. Bronsted, and Dr. A. W. Brøgger will review recent evidence bearing on the iron age in Norway. Mr. E. MacNeil will deal with the Picts, Mr. C. Hawkes with the relations of iron age enclosures in Britain and on the Continent, and last, but by no means least in interest, Mr. E. T. Leeds will review the evidence for the penetration of the Saxons into the upper Thames region.

\section{University and Educational Intelligence}

EdINBURGH.-Curricula for the degree of B.Sc. with honours in anthropology have been approved.

Following on the resignation of Dr. C. B. Williams of the loctureship in agricultural and forest entomology, the two lectureships in entomology in the University have been more closely correlated. Dr. A. E. Cameron, at present lecturor in modical entomology, has been placed in general charge of the instruction in entomology in the University, and Mr.J.W.McHardy, formerly entomologist attached to the Medical Department of Tanganyika Territory, has been appointed as the other lecturer in entomology.

Prof. A. J. D. Porteous, MeGill University, has been appointed to the lectureship in ancient philosophy about to be vacated by the resignation of Mr. R. P. Hardie.

Intimation has been received of the following resignations: Dr. T. W. M. Cameron, lecturer in helminthology, on appointment as research professor in helminthology at MeGill University; Mr. A. D. Hobson, lecturer in zoology, on appointment to the chair of zoology at Armstrong College, Newcastle; Dr. Edward L. Ince, lecturer in mathematics, on appointment to the Imperial College of Science, South Kensington, London.

LONDON.-University post-graduate travelling studentships of the value of $£ 275$ for one year have been awarded to Dr. B. W. Bradford (Imperial College of Science and Technology) and Muriel H. E. Long (King's College and King's College Hospital). Dr. Bradford proposes to study the adsorption of gases on metals with particular reference to polar fuctors, at Frankfort-on-Main, and Miss Long will study surgery and its practice in Vienna, Cologne, Berlin, and Budapest, making Vienna her base, and specialising in stomach surgery.

Prof. A. C. Menzies, professor of physies at University College, Leicester, has been appointed professor of physics at University College, Southampton.

ECONOMIC depression and unemployment in America have stimulated interest and activity in what is known as the 'educational guidance' movement. An official report on recent developments of the movement is published in School Life for May, which also contains an editorial describing how continuation and other schools in various parts of the country are adapting their resources to the task of aiding the unemployed. Among the evidences of increased attention to educational guidance is an increase in the number of schools providing organised guidance services. In Pennsylvania alone 800 now have counsellors or advisers on an extra-curricular, part-time or full-time basis, or have established group guidance through classes in opportunities or occupations. Many State and local communities are organising associations for promoting public-school guidance programmes. Guidance figures more largely in programmes of educational conferences, local, State, and national. The output of literature bearing on the subject is enormous, including textbooks for teachers' training colleges, occupational studies issued by directors of education, roports issued by associations such as the Amorican Vocational Association, vocational surveys and monographs by research workers. Educational broadcasting programmes also give prominence to vocational guidance, while State departments are including guidance work in State courses of study. In Idaho, the State Board of Education has arranged for the formulation of a State guidance programme.

No. 3272, VoL. 130] 